\title{
Neutrophils as one of the major haptoglobin sources in mastitis affected milk
}

\author{
I-Hsiang LaI ${ }^{1}$, Jung Hsu TsaO ${ }^{2}$, Yi Ping $\mathrm{Lu}^{3}$, Jai Wei $\mathrm{LeE}^{4}$, Xin $\mathrm{ZHAO}^{5}$, \\ Feng Lin ChIEN ${ }^{1}$, Simon J.T. MAO ${ }^{1,6 *}$ \\ ${ }^{1}$ Institute of Biochemical Engineering, College of Biological Science and Technology, \\ National Chiao Tung University, 75 Po-Ai Street, Hsinchu, Taiwan, R.O.C. \\ ${ }^{2}$ Yong Rong Dairy Farm, Chyayi, Taiwan, R.O.C. \\ ${ }^{3}$ Pingtung County Livestock Disease Control Center, Pingtung, Taiwan, R.O.C. \\ ${ }^{4}$ Department of Tropical Agriculture and International Cooperation, \\ National Pingtung University of Science and Technology, Pingtung, Taiwan, R.O.C. \\ ${ }^{5}$ Department of Animal Science, McGill University, Quebec, Canada \\ ${ }^{6}$ Department of Biotechnology, Asia University, Taichung, Taiwan, R.O.C.
}

(Received 17 July 2008; accepted 16 December 2008)

\begin{abstract}
The antioxidant haptoglobin $(\mathrm{Hp})$ is an acute-phase protein responsive to infectious and inflammatory diseases. Hp and somatic cell counts (SCC) are sharply elevated in bovine milk following intramammary administration of endotoxin or bacteria. However, the sources of milk $\mathrm{Hp}$ responsible for such increases are not fully understood. The purpose of this study was to define the source of milk $\mathrm{Hp}$ from dairy cows with naturally occurring mastitis. Quarter milk samples selected from 50 dairy cows were separated into four groups according to SCC as group A: $<100(n=19)$; B: $100-200(n=10)$; C: $201-500(n=10)$; and D: $>500 \times 10^{3}(n=11)$ cells $/ \mathrm{mL}$. Our results reveal that milk $\mathrm{Hp}$ concentrations were correlated with $\mathrm{SCC}(r=0.742 ; P<0.01)$, and concentrations in group D were $\sim 10$-fold higher than in group A. Reverse transcriptase-polymerase chain reaction (RT-PCR) analysis indicates that the milk somatic cells from group D were not only capable of synthesizing Hp but could also markedly increase Hp mRNA expression. Western blot, immunocytochemistry, double confocal immunofluorescence, and $\mathrm{Hp}$ releasing experiments demonstrate that neutrophils were associated with the biosynthesis and release of Hp in milk. It further shows that $\mathrm{Hp}$ was significantly elevated in the epithelium of mammary gland tissue with mastitis and was also expressed in the cultured mammary epithelial cells. We propose that neutrophils and epithelial cells may play an essential role in elevating milk $\mathrm{Hp}$ in addition to previous suggestions that Hp may be derived from mammary tissues and circulation.
\end{abstract}

haptoglobin / neutrophil / mastitis / MAC-T cells / immunocytochemistry

\section{INTRODUCTION}

Haptoglobin ( $\mathrm{Hp})$ is an acute phase protein responsive to inflammation and infection $[6,7$, 24]. One of the major functions of $\mathrm{Hp}$ is to

\footnotetext{
* Corresponding author: mao1010@ms7.hinet.net
}

capture released hemoglobin during excessive hemolysis [12] and to scavenge the hemoglobininduced free radicals during oxidative stress [16]. We have recently shown that $\mathrm{Hp}$ is an extremely potent antioxidant that directly prevents low-density-lipoproteins from $\mathrm{Cu}^{2+}$ - and radical compound-induced oxidation $[13,30]$. 
Transfection of Hp cDNA into Chinese hamster ovary cells protects them against oxidative stress [30]. Structurally, bovine $\mathrm{Hp}$ is unique possessing only the Hp 2-2 phenotype [14, 15] with a molecular weight ranged from 660 to $730 \mathrm{kDa}$ [15] which is different from that of humans expressed as Hp 1-1, 2-1, or $2-2$.

Bovine Hp, while not abundantly expressed in normal plasma, is considered to be one of the sensitive acute phase proteins during bacterial infections $[15,24]$. Several studies indicate that its concentration increases dramatically in both plasma and milk during clinical mastitis of dairy cows $[6,8,21]$. In experimentally induced mastitis by intramammary bacterial-challenge with Streptococcus uberis, the observed increase in milk Hp has been suggested to originate from the circulation [23]. Hiss et al. [9] also found elevated $\mathrm{Hp}$ in milk after intramammary endotoxin challenge. It was further observed that Hp could be locally synthesized within the mammary gland [9]. The source of milk Hp found in naturally occurring mastitis is poorly understood.

The purpose of the present study was to define the source of milk Hp from dairy cows with high somatic cell counts (SCC) (or mastitis). We investigated milk somatic cells for the presence of $\mathrm{Hp}$ protein using Western blot, Hp mRNA expression using reverse transcriptase-polymerase chain reaction (RT-PCR), partial cell typing using double confocal immunofluorescence, and endogenously released $\mathrm{Hp}$ using ELISA. Finally, we localized $\mathrm{Hp}$ in normal and mastitic mammary gland tissue and in a cultured mammary epithelial cell line (MAC-T). Our findings show that the increased Hp was associated with neutrophils, in which $\mathrm{Hp}$ was released into the medium in an ex vivo experiment. In mastitis mammary glands, Hp was mainly localized within the epithelial cells. We also observed for the first time that cultured epithelial MAC-T cells could synthesize $\mathrm{Hp}$ in vitro. In addition to locally synthesized Hp within the mammary gland and $\mathrm{Hp}$ transferred from the circulation, we propose that milk neutrophils and mammary epithelium also contribute to milk $\mathrm{Hp}$ concentrations.

\section{MATERIALS AND METHODS}

\subsection{Sample collection and SCC}

Quarter milk samples from individual cows (Bos taurus) were collected at the Yong Rong Dairy Farm (Chyayi, Taiwan). SCC in each sample was measured using a Fossomatic 4000 cell counter (Foss Electric, Hillerød, Denmark) at the Livestock Research Institute, Council of Agriculture, Executive Yuan (Hsinchu, Taiwan). Quarter milk samples were then selected and assigned to four groups according to SCC (A: < 100; B: 100-200; C: 201-500; and $\mathrm{D}:>500 \times 10^{3}$ cells $/ \mathrm{mL}$ with $n=19,10,10$, and 11 , respectively).

\subsection{Purification of bovine $\mathrm{Hp}$ and preparation of anti-Hp antibodies}

Native bovine Hp was isolated from the plasma using an anti-bovine Hp immunoaffinity column, followed by gel-permeation chromatography (Superose12) on a HPLC system as previously described [15]. Mouse and rabbit polyclonal antibodies against bovine recombinant $\mathrm{Hp}$ or mouse monoclonal antibody (mAb; $2 \mathrm{H} 12)$ against bovine native $\mathrm{Hp}$ were prepared in our laboratory according to previously established procedures $[3,15]$.

\subsection{Determination of milk Hp levels using ELISA}

Bovine milk Hp concentrations were determined using a commercial bovine Hp ELISA kit (Immunology Consultants Laboratory, Newberg, OR, USA) according to the manufacture's instructions. One hundred $\mu \mathrm{L}$ of skimmed milk (1:10 dilution) were used for the determination of $\mathrm{Hp}$, while skimmed milk was prepared as previously described [2].

\subsection{Isolation of milk somatic cells and protein extraction}

Milk somatic cells were isolated from $200 \mathrm{~mL}$ freshly collected milk. Briefly, milk samples maintained at $4{ }^{\circ} \mathrm{C}$ were centrifuged at $1000 \mathrm{~g}$ for $20 \mathrm{~min}$ at $4{ }^{\circ} \mathrm{C}$. After removing the fat layer and supernatant, the somatic cells were briefly washed twice with PBS at $4{ }^{\circ} \mathrm{C}$ and maintained on ice. Total cell proteins were extracted using a lysis buffer containing $0.3 \%$ Triton X-100 in PBS and sonicated at $4{ }^{\circ} \mathrm{C}$ for $5 \mathrm{~min}$, followed by centrifugation at $10000 \mathrm{~g}$ for $10 \mathrm{~min}$ at $4{ }^{\circ} \mathrm{C}$. The remaining 
supernatant was stored at $-20{ }^{\circ} \mathrm{C}$ until analysis by SDS-PAGE and Western blot.

\subsection{Gel electrophoresis and Western blot}

SDS-PAGE was carried out on 1.5-mm-thick slab gel, using a discontinuous system as previously described [14]. Unless otherwise specified, the gel containing $15 \%$ (for reducing) or $4 \%$ (for nonreducing samples) polyacrylamide was used with a top stacking gel of $5 \%$ polyacrylamide. Approximately $20 \mu \mathrm{g}$ of the protein was loaded onto the gels and each tested sample was preheated at $100{ }^{\circ} \mathrm{C}$ for $10 \mathrm{~min}$ in a loading buffer $(12 \mathrm{mM}$ Tris- $\mathrm{HCl}, \mathrm{pH}$ $6.8,0.4 \%$ SDS, $5 \%$ glycerol, $0.02 \%$ bromphenol blue) with or without $140 \mathrm{mM}$ 2-mercaptoethanol. The samples were then run for about $1.5 \mathrm{~h}$ at $100 \mathrm{~V}$ and stained by Coomassie brilliant blue. Molecular-mass standard containing 12 prestained proteins $(3.5-260 \mathrm{kDa})$ was purchased from Invitrogen (Carlsbad, CA, USA). Western blot analysis was performed similar to that described previously [13].

\subsection{Analysis of Hp mRNA expression of milk somatic cells}

Total RNA was extracted from milk somatic cells using an RNeasy mini kit (Qiagen, Hilden, Germany) according to the manufacture's instructions. The first strand cDNA was synthesized using moloney murine leukemia virus (MMLV) reverse transcriptase (Invitrogen). Briefly, equal amounts of total RNA $(1 \mu \mathrm{g})$ were added to a reaction mixture containing $50 \mathrm{mM}$ Tris- $\mathrm{HCl}(\mathrm{pH} 8.3), 10 \mathrm{mM}$ dithiothreitol, $0.5 \mu \mathrm{g}$ oligo (dT) $)_{18}, 75 \mathrm{mM} \mathrm{KCl}, 3 \mathrm{mM} \mathrm{MgCl}_{2}$, $0.5 \mathrm{mM}$ dNTP mix, $40 \mathrm{U}$ RNase inhibitor, and 200 U MMLV reverse transcriptase, and proceeded at $37{ }^{\circ} \mathrm{C}$ for $50 \mathrm{~min}$, followed by $70{ }^{\circ} \mathrm{C}$ for $15 \mathrm{~min}$. Equal amounts of total cDNA (100 ng) were amplified by PCR using Hp specific primers, while using glyceraldehyde 3-phosphate dehydrogenase (GAP$\mathrm{DH})$ as a house-keeping control. The primer design was based on the published nucleotide sequence of bovine Hp [15] with 5'-TGCTGCAGGGATCATC GGTGGCTCATTGGA-3' and 5'-CGGAAAACCAT CGCTAACAACTAAGCTTGGG- ${ }^{\prime}$ as the forward and reverse primer, respectively. The GAPDH primers prepared were $5^{\prime}$-CCTGGAGAAACCTGCCA AGT-3' (forward) and 5'-GCCAAATTCATTGTC GTACCA-3' (reverse). The PCR cycling profile was $95{ }^{\circ} \mathrm{C}$ for $5 \mathrm{~min}$ followed by 30 cycles at $94{ }^{\circ} \mathrm{C}$ for $30,55^{\circ} \mathrm{C}$ for $30 \mathrm{~s}, 72{ }^{\circ} \mathrm{C}$ for $50 \mathrm{~s}$ (or $30 \mathrm{~s}$ in GAPDH) with a final extension at $72{ }^{\circ} \mathrm{C}$ for $10 \mathrm{~min}$. The RT-PCR products (214 bp for GAP$\mathrm{DH}$ and $755 \mathrm{bp}$ for Hp) were resolved on $1.5 \%$ agarose gel [14], followed by an ethidium bromide staining. The band intensity corresponding to $\mathrm{Hp}$ was determined using a Quantity One software of Gel Doc 2000 Gel Documentation System (BioRad Laboratories, Hercules, CA, USA).

\subsection{MAC-T and Hp mRNA expression}

MAC-T, an established and immortalized epithelial cell line isolated from bovine mammary tissue was cultured as previously described $[10,18]$. In general, the cells $\left(1 \times 10^{4}\right.$ cells per well $)$ were grown at $37{ }^{\circ} \mathrm{C}\left(5 \% \mathrm{CO}_{2}\right)$ in a 24-well culture plate in complete Dulbecco modified Eagle medium (Invitrogen) supplemented with $10 \%$ fetal bovine serum (containing no immunoreactive bovine $\mathrm{Hp}$ ), $50 \mu \mathrm{g} / \mathrm{mL}$ of streptomycin, and $50 \mathrm{IU} / \mathrm{mL}$ of penicillin (Invitrogen). Hp mRNA expression was analyzed using RT-PCR similar to the procedures described above.

\subsection{Immunocytochemical staining of somatic and MAC-T cells and mammary tissues}

The labeled streptavidin biotin kit (LSAB) (Dakocytomation, Glostrup, Denmark) was used for immunostaining according to the manufacturer's instructions. In brief, cytospins containing freshly isolated somatic or MAC-T cells were treated with ice-chilled methanol (100\%) for $15 \mathrm{~min}$ and then rehydrated by PBS. The cells were permeabilized in PBS containing $0.3 \%$ Triton X-100 for $10 \mathrm{~min}$, while the endogenous peroxidase was blocked by incubation with $3 \% \mathrm{H}_{2} \mathrm{O}_{2}$. After blocking with $2 \%$ gelatin, the cells were incubated with unlabeled mouse anti-CD5 $\mathrm{mAb}$ (lymphocyte marker), mouse anti-CD11b mAb (neutrophil marker) (Serotec, Oxford, UK), or mouse anti-Hp polyclonal antibody for $1 \mathrm{~h}$. The slides were then incubated with biotinylated anti-mouse IgG for $30 \mathrm{~min}$, followed by washes and incubation with HRP-conjugated streptavidin for $30 \mathrm{~min}$. After washes, the slides were developed with 3-amino9-ethylcarbazole or 3,3'-diaminobenzidine (DAB) substrate and counterstained with hematoxylin. For normal and mastitic mammary tissues $(n=5$ each), each section was deparaffinized in a $50{ }^{\circ} \mathrm{C}$ oven for $10 \mathrm{~min}$ and then placed for two 5-min washes in xylene at $24{ }^{\circ} \mathrm{C}$. The sections were rehydrated through sequential soakings in $100,95,90,80$, and $50 \%$ alcohol for $2 \mathrm{~min}$ each, followed by final washes in deionized water. The sections were then stained using procedures described above. 


\subsection{Double immunofluorescence using confocal laser scanning microscopy}

Cytospin prepared cells used for localization of $\mathrm{CD} 11 \mathrm{~b}$ and $\mathrm{Hp}$ were permeabilized as described above. After blocking, the cells were co-incubated with unlabeled mouse anti-CD11b mAb and rabbit anti-Hp polyclonal antibody for $1 \mathrm{~h}$. The slides were then incubated with a mixture of fluorescent isothiocyanate (FITC) conjugated anti-mouse $\operatorname{IgG}$ and rhodamine conjugated anti-rabbit IgG (Jackson Immunoresearch Laboratories, West Grove, PA, USA) for $1 \mathrm{~h}$ in the dark. The cells were washed with PBS before examination using a Fluoview FV500 confocal laser scanning microscopy (Olympus, Tokyo, Japan).

\subsection{Time course of Hp protein released from somatic cells in vitro}

Two $\mathrm{mL}$ of isolated somatic cells (adjusted to $1 \times 10^{4}$ cells $/ \mathrm{mL}$ at $4{ }^{\circ} \mathrm{C}$ ) from groups $\mathrm{A}$ and $\mathrm{D}$ $(n=3$ for each) were suspended in Roswell Park Memorial Institute medium (RPMI) 1640 medium (JRH Biosciences, Lenexa, KS, USA) containing $100 \mu \mathrm{g} / \mathrm{mL}$ ampicillin with or without protease inhibitor of $1 \mathrm{mM}$ phenylmethylsulfonyl fluoride (PMSF) (Sigma, St. Louis, MO, USA) in a test tube and were incubated at $37^{\circ} \mathrm{C}$ for $0,2,4,8$ and $16 \mathrm{~h}$, respectively, followed by centrifugation at $1000 \mathrm{~g}$ at $4{ }^{\circ} \mathrm{C}$ for $5 \mathrm{~min}$. The supernatant was then subjected to ELISA for the determination of $\mathrm{Hp}$ concentrations.

\section{RESULTS}

\subsection{Correlation between Hp levels and SCC in bovine milk}

Selected bovine milk samples $(n=50)$ were assigned into four groups according to their SCC (A: < 100; B: 100-200; C: 201-500; and $\mathrm{D}:>500 \times 10^{3}$ cells $/ \mathrm{mL}$ with $n=9,10$, 10 , and 11 , respectively). The mean \pm SEM of milk $\mathrm{Hp}$ concentrations determined by an ELISA in groups $\mathrm{A}, \mathrm{B}, \mathrm{C}$, and $\mathrm{D}$ were $0.23 \pm 0.08, \quad 0.74 \pm 0.23, \quad 1.11 \pm 0.28$, and $2.22 \pm 0.53 \mu \mathrm{g} / \mathrm{mL}$, respectively. The mean Hp concentration of group D was $\sim 10$-fold higher than that of group A $(P<0.001)$. The overall $\mathrm{Hp}$ concentrations were correlated with $\operatorname{SCC}(r=0.742 ; P<0.01)$.

\subsection{Hp in milk somatic cells}

Because Hp levels in the milk samples were positively correlated with SCC, we hypothesized that somatic cells might contribute to the presence of $\mathrm{Hp}$ in milk. We extracted protein from the somatic cells from the low (group A) and high SCC (group D) to examine the presence of $\mathrm{Hp}$ using a Western blot. Figure 1 depicts the presence of $\mathrm{Hp}$ in group $\mathrm{D}$, but not in group A. It implicates the endogenous synthesis and expression of Hp between the analyzed cells of groups A and D was different or/and altered. The electrophoretic pattern of bovine $\mathrm{Hp}$ (non-reduced) was similar to that previously reported by our laboratory [15].

\subsection{Endogenous expression of Hp mRNA in milk somatic cells}

To determine whether somatic cells could endogenously synthesize Hp, RT-PCR for the expression of Hp mRNA was conducted, while using GAPDH as a house-keeping control. Figure 2 shows that the Hp mRNA expression was progressively increased with the SCC $(P<0.001)$. The mean Hp mRNA expression in groups $\mathrm{C}$ and $\mathrm{D}$ were evidently higher than those in groups $\mathrm{A}$ and $\mathrm{B}(P<0.001)$.

\subsection{Somatic cell typing}

To identify the cell types in group D, we used anti-CD5 (lymphocyte marker) and anti$\mathrm{CD} 11 \mathrm{~b}$ (neutrophil marker) $\mathrm{mAb}$ as a probe in immunostaining, while comparing group A as a non-mastitis control. We found lymphocytes to be a major cell type in group A and neutrophils the predominant cell type in group $\mathrm{D}$ (data not shown). The immunostaining was specific because the background control using non-immuned sera or non-related $\mathrm{mAb}$ was negative (data not shown).

\subsection{Colocalization of $\mathrm{Hp}$ and CD11b in neutrophils using confocal microscopy}

In addition to RT-PCR, we tested whether neutrophils could express Hp in situ. Somatic cells isolated from group D enriched with 
(A) $15 \%$ SDS-PAGE

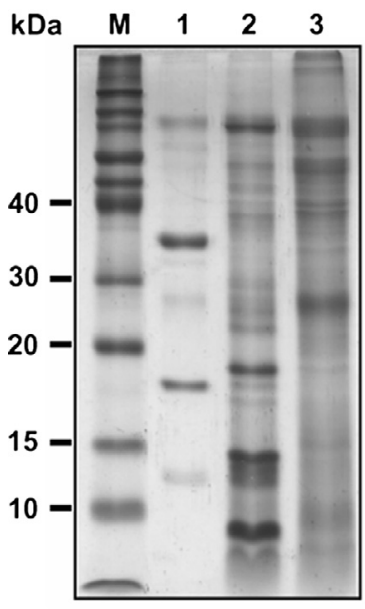

Coomassie blue
(B) Western blot

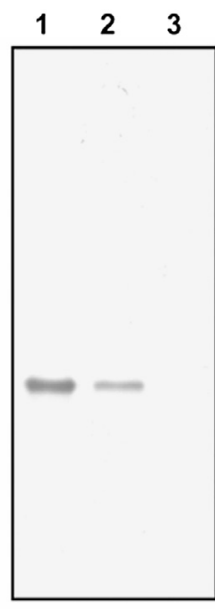

Reducing

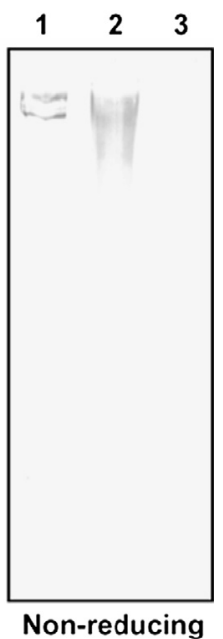

Non-reducing

1. Isolated $\mathrm{Hp}$

2. Somatic cells lysate of group D

3. Somatic cells lysate of group A

Figure 1. Typical SDS-PAGE pattern and Western blot analyses of milk somatic cell lysates from groups $\mathrm{A}$ and D. (A) Coomassie blue staining of somatic cell lysates run on a $15 \%$ SDS-PAGE under reducing conditions. (B) Western blot analysis of the isolated Hp and somatic cell lysates under reducing (left panel with $15 \%$ SDS-PAGE) and non-reducing conditions (right panel with $4 \%$ SDS-PAGE) using a mouse polyclonal antibody prepared against bovine recombinant $\mathrm{Hp}$. Lane $\mathrm{M}$, molecular markers in $\mathrm{kDa}$.

neutrophils were examined for localization of Hp using a double confocal laser scanning microscopy. Figure 3 shows that all the neutrophils identified by CD11b (in green FITC) exhibited expression of $\mathrm{Hp}$ (in red rhodamine), while no staining was observed for cells treated with non-immuned sera nor unrelated $\mathrm{mAb}$ (data not shown).

\subsection{Release of $\mathrm{Hp}$ from the somatic cell ex vivo}

To test the hypothesis that the neutrophil enriched population secreted $\mathrm{Hp}$, we collected the somatic cells from the groups A and D ( $n=3$ quarters for each) and investigated their Hp secretion into the RPMI 1640 medium over time. Figure 4 shows that both groups were able to secrete $\mathrm{Hp}$ into the medium with a markedly greater secretion in group $\mathrm{D}$ than in group A. Essentially, the released $\mathrm{Hp}$ reached maximal levels within the first $2 \mathrm{~h}$ tested. Thus, the milk neutrophils not only express Hp but also release it into the milk.

\subsection{Localization of $\mathrm{Hp}$ in mammary tissue and MAC-T cell}

We used mouse anti-bovine Hp polyclonal antibody to localize the bovine Hp near the area of alveoli in mammary tissues $(n=5)$. The results indicate that only mastitic mammary tissue expressed $\mathrm{Hp}$ relative to normal tissue. Figures $5 \mathrm{~A}$ and $5 \mathrm{~B}$ illustrate a typical example showing that Hp was primarily localized at alveoli of mastitic mammary tissue, but not in the normal tissues (Figs. 5C and 5D). To provide additional evidence that mammary alveolar epithelial cells can express Hp, we showed that cultured- MAC-T cells were able to express Hp mRNA (panel of Fig. 5E). We further demonstrated the presence of Hp protein in MAC-T cells using immunocytochemical staining (Figs. 5E and 5F). 

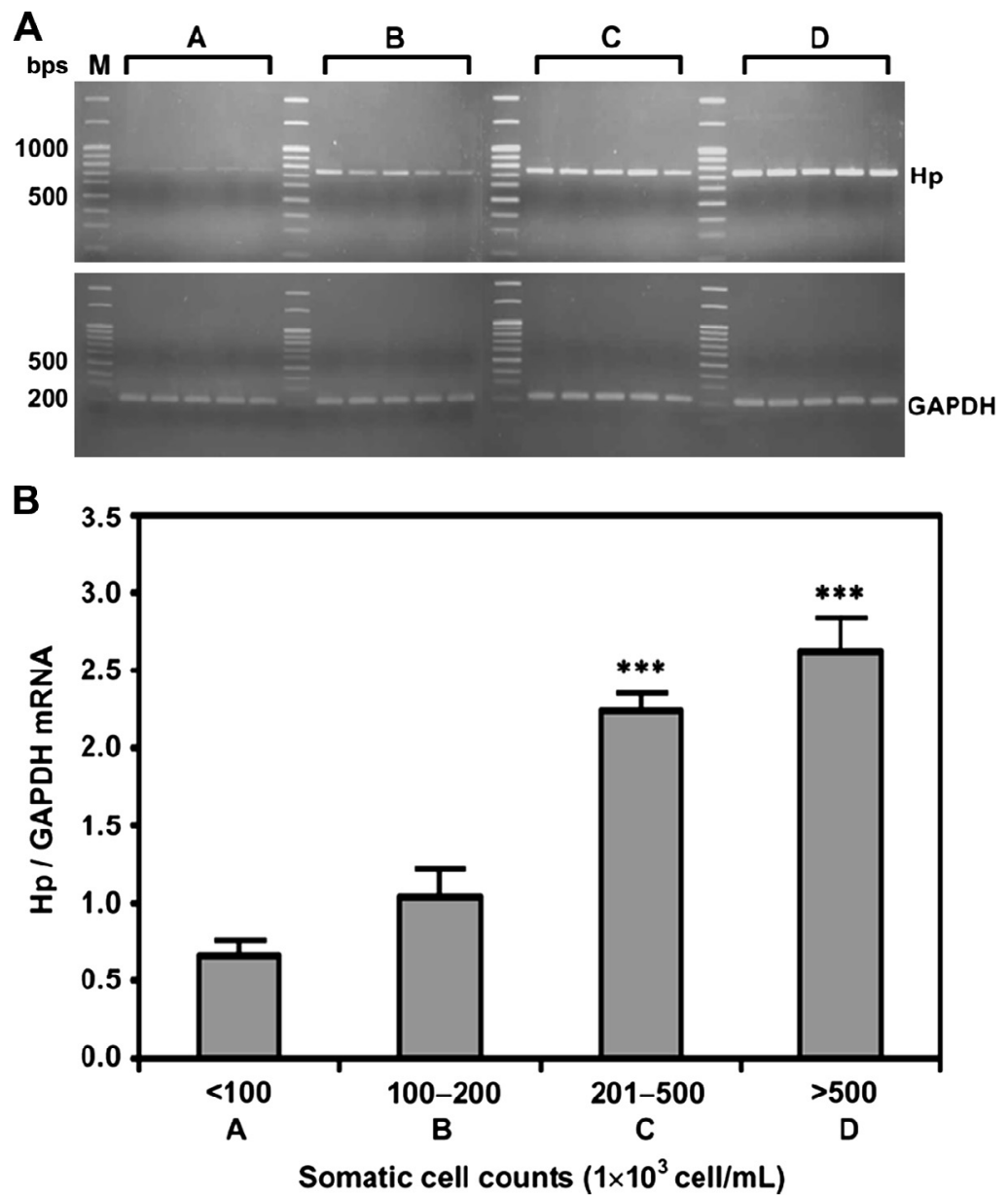

Figure 2. Expression levels of Hp mRNA in somatic cells. (A) Expression of Hp mRNA in milk somatic cells according to SCC (A: < 100; B: 100-200; C: 201-500; and D: $>500 \times 10^{3}$ cells $/ \mathrm{mL}$ with $n=5$ in each group). An equal amount of total cDNA (100 ng) was amplified by PCR, using GAPDH as a housekeeping control. (B) Each bar represents the mean \pm SEM. ${ }^{* * *} P<0.001$ as compared to group A.

\section{DISCUSSION}

\subsection{Correlation between Hp levels and SCC in bovine milk}

The SCC of milk has been utilized as an indicator of mastitis because of its simple handling procedures. In general, SCC of a quarter greater than $500 \times 10^{3}$ cells $/ \mathrm{mL}$ is considered to be associated with mastitis $[22,26]$. A limit of $\leq 100 \times 10^{3}$ cells/mL has been suggested for a healthy quarter [19]. If the SCC exceeds
$200 \times 10^{3}$ cells $/ \mathrm{mL}$, the quarter is likely to be infected [25]. The results from the present study showed a 10 -fold increase in Hp concentrations in milk containing SCC $>500 \times 10^{3}$ (group D) relative to $\mathrm{SCC}<100 \times 10^{3}$ (group A). This suggests that the somatic cells were responsible for the elevation of $\mathrm{Hp}$ in milk, at least in part.

\subsection{Bovine $\mathrm{Hp}$ in milk somatic cells}

Previous studies have proposed that milk Hp can be derived from mammary tissues and 

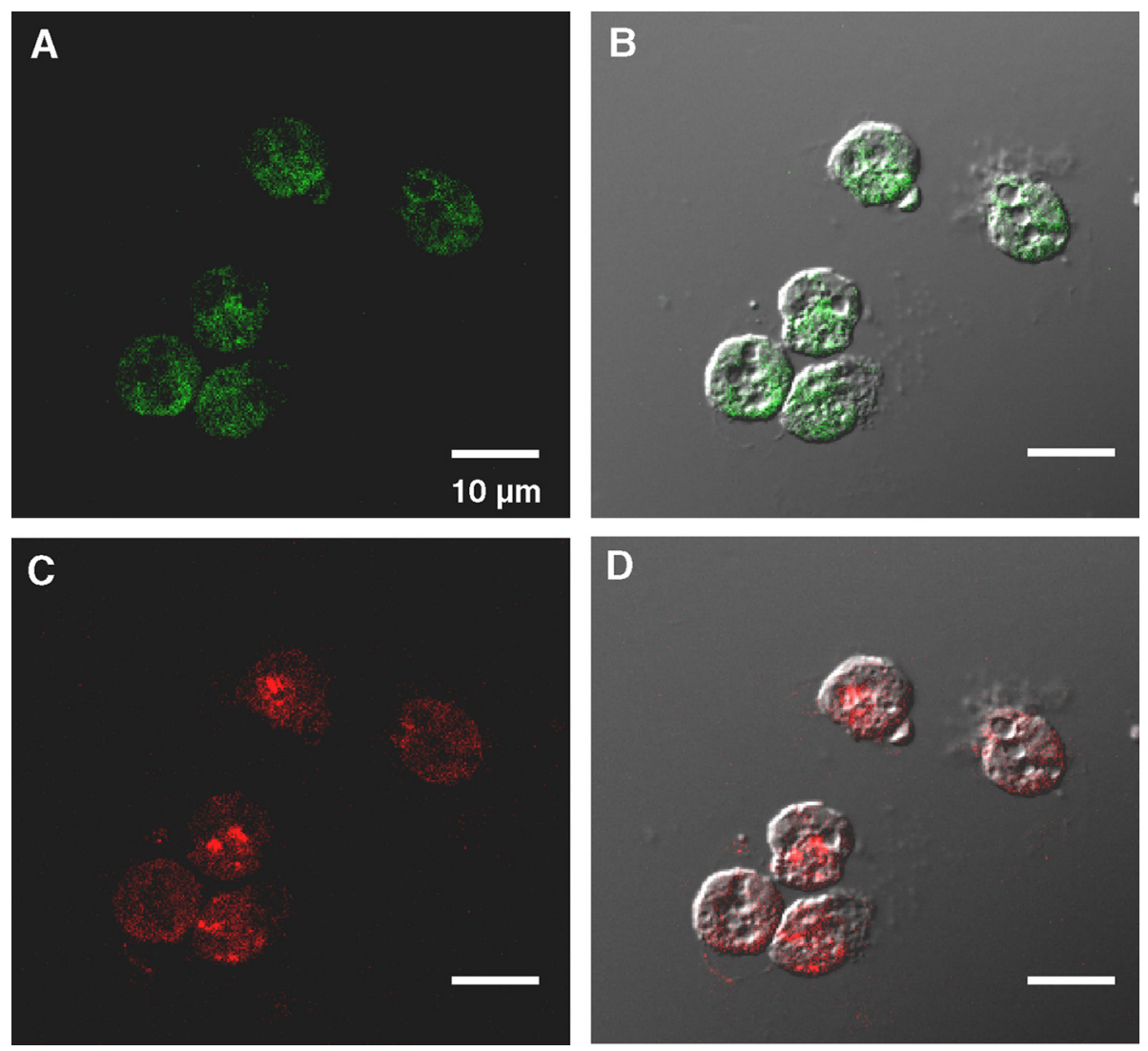

Figure 3. Colocalization of $\mathrm{CD} 11 \mathrm{~b}$ and $\mathrm{Hp}$ in milk neutrophils using confocal laser scanning microscopy. $\mathrm{CD} 11 \mathrm{~b}$ as a marker for neutrophils was visualized with a FITC-conjugated second antibody (A and B). Likewise, Hp was visualized with a rhodamine-conjugated second antibody (C and D).

circulating blood following intramammary infection $[5,9]$. Although the factors attributed to the elevated milk $\mathrm{Hp}$ in naturally occurring mastitis are not fully understood, the present study suggests that neutrophils in milk are a major source of milk $\mathrm{Hp}$ in cows with mastitis. There are several lines of evidence to support this notion. First, Hp levels determined by ELISA were positively correlated with the SCC in our group analyses in which the increase in SCC was mostly attributed to neutrophils. Second, using Western blot analysis, Hp was found abundantly in the cell lysate of group D, but not in that of the normal group A (Fig. 1). A recent study using matrix assisted laser desorption ionization-time of flight-mass indicates that $\mathrm{Hp}$ is present and concentrated within the granules of bovine granulocytes isolated from peripheral blood of healthy cattle, although the cell types (such as neutrophils) have not been specified [4]. Third, the Hp mRNA levels in cells of the high SCC groups B-D were significantly higher than in the cells of the normal group A. The underlying mechanism involved in high $\mathrm{Hp}$ expression in the higher SCC groups appears to be related to the different cell types. We also observed that neutrophils were the predominate cell type in group D, but not in group A when examined by immunocytochemistry (data not shown). This suggests that neutrophils in high SCC milk account for the major synthesis of Hp. Furthermore, using laser confocal scanning 


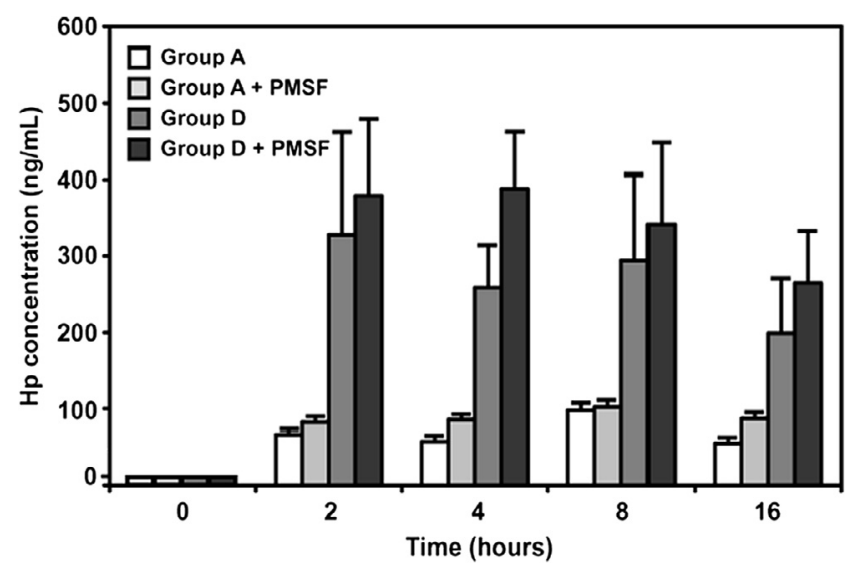

Figure 4. Time course of Hp protein released into RPMI 1640 medium by somatic cells from groups A and $\mathrm{D}$ ex vivo. Freshly isolated somatic cells from milk samples of groups A and D ( $n=3$ of each group) at $4{ }^{\circ} \mathrm{C}$ were immediately suspended in RPMI 1640 and kept at $37^{\circ} \mathrm{C}$ over time. Supernatant containing Hp was determined using an ELISA. Protease inhibitor (PMSF) was also added in parallel to each group in an attempt to minimize the Hp degradation. Each bar represents the mean \pm SEM.

microscopy, we observed that all the neutrophils isolated from the somatic cells were capable of expressing $\mathrm{Hp}$ as determined by double immunofluorescence (Fig. 3). Fourth, these cells not only synthesized Hp but also released it into milk (Fig. 4).

This is the first study demonstrating that Hp is synthesized by cattle neutrophils using RT-PCR, which is inconsistent with an early report indicating that human neutrophils do not produce $\mathrm{Hp}$ [32]. In that study, the authors hypothesized that $\mathrm{Hp}$ of neutrophils was derived from the liver and stored in specific granules via endocytosis [32]. While conducting our investigation, a recent study appeared, reporting that $\mathrm{Hp}$ can be released from human neutrophils [28] indicating the presence of $\mathrm{Hp}$ mRNA in human neutrophils, although the level of expression was minimal. Taken together, it is conceivable that neutrophils may contribute to the increased level of $\mathrm{Hp}$ in milk from cows with mastitis.

\subsection{Milk Hp from the other sources}

It has been shown that Hp is expressed in the mammary tissue using ELISA and RT-PCR, although the cell types involved were not specified [9]. Using an epithelial cell line (MAC-T) and mammary gland tissue sections we further demonstrate that epithelial cells were able to endogenously synthesize and express Hp (Fig. 5), which is consistent with the results by Thielen et al. [29] using an in situ hybridization on the epithelium of mastitic mammary tissue. Another study has also suspected the presence of $\mathrm{Hp}$ in the epithelium of alveolus [6]. Nonetheless, the localization of $\mathrm{Hp}$ in bovine alveolar epithelium of mastitic tissue or cultured MAC-T cells is now demonstrated in the present study (Fig. 5).

\subsection{Remarks on Hp secretion in milk and its physiologic function}

This study shows that neutrophils and mammary epithelial cells represent an additional extra-hepatic source of $\mathrm{Hp}$ in milk. The possible mechanism by which neutrophils migrate into the alveolus of mammary gland and how $\mathrm{Hp}$ is recruited in milk are explained and summarized in Figure 6.

The physiologic benefits of local $\mathrm{Hp}$ expression in mammary tissue during infection 

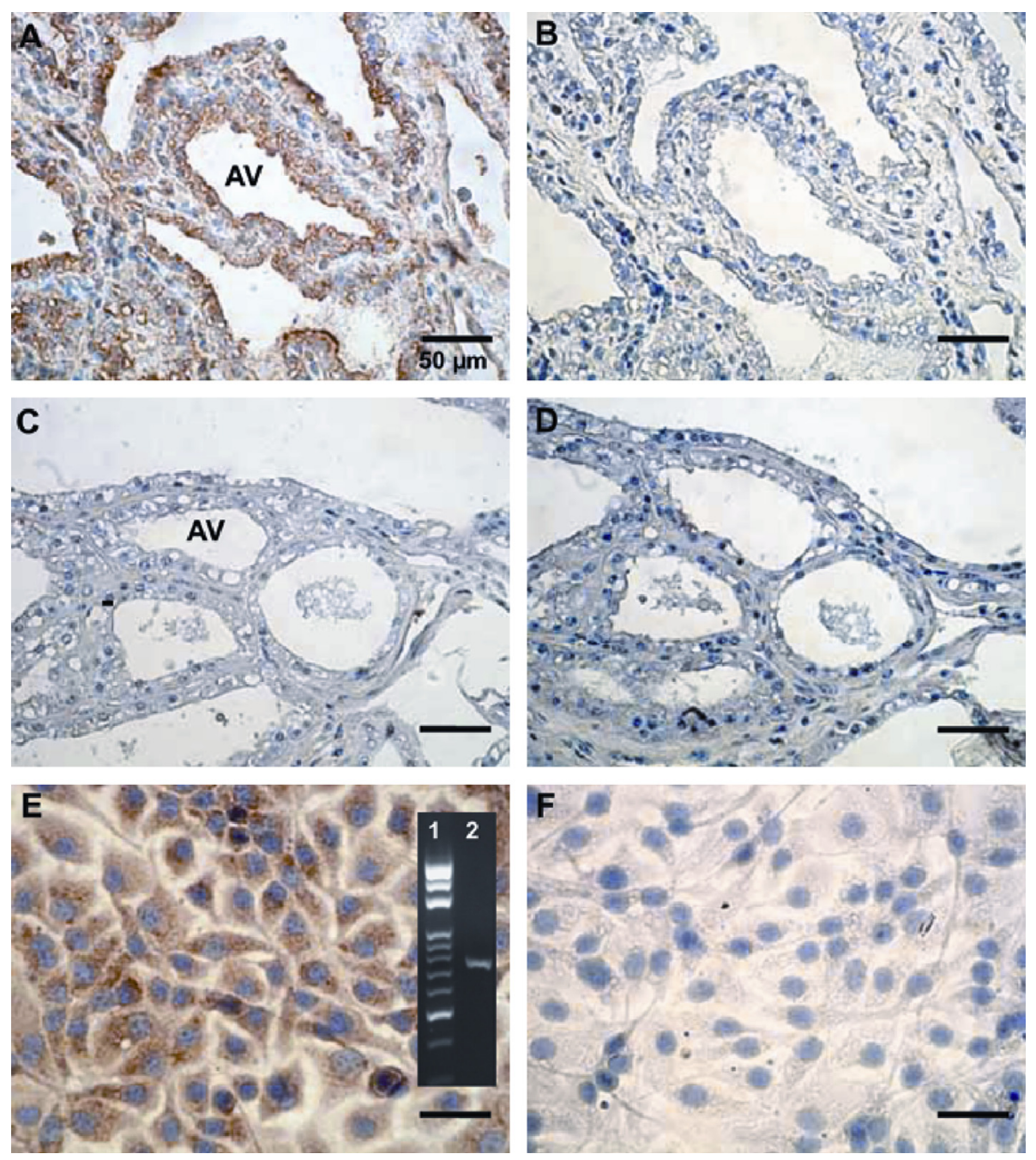

Figure 5. Immunocytochemical localization of $\mathrm{Hp}$ in mammary gland and MAC-T cells. Mammary tissues with (A and $\mathrm{B})$ and without mastitis $(\mathrm{C}$ and $\mathrm{D})$ were incubated with mouse anti-Hp polyclonal antibodies (A and $\mathrm{C}$ ), while using normal non-immuned mouse serum as a negative control (B and D). MAC-T cells were incubated with mouse anti-Hp polyclonal antibodies (E), while using normal non-immuned mouse serum as a negative control (F). DAB was used as a chromogenic substrate for $\mathrm{Hp}$ staining (in brown) and hematoxylin was employed as a nuclear stain (in blue). Panel in E represents the Hp mRNA expression (Lane 2) and DNA molecular weight markers (Lane 1) using RT-PCR. AV = alveolar.

remain illusive. During mastitis, activated neutrophils produce significant amounts of reactive oxygen species (in order to kill the bacteria) which may cause tissue damage $[1,17,31]$. Hp is an extremely potent antioxidant that can directly scavenge free radicals, it may effectively utilize Hp to attenuate such intracellular damage [30]. A further understanding of the role played by neutrophils as a source of $\mathrm{Hp}$ may provide insight into the understanding of an additional function of neutrophils in milk. 


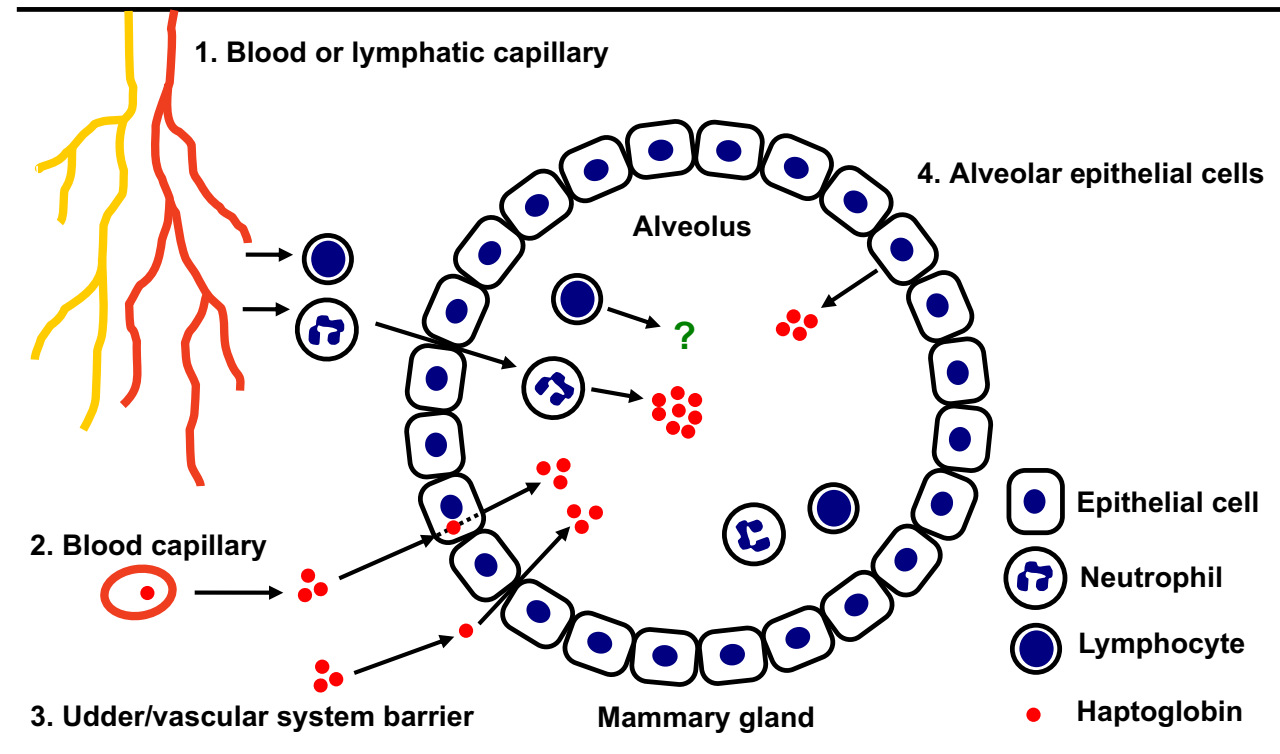

Figure 6. Schematic diagram of hypothetical pathways for the presence of bovine Hp in milk. There are at least four combined possible pathways for the presence of $\mathrm{Hp}$ in milk during mastitis. First, inflammatory cytokines (TNF- $\alpha$, IL-1 $\beta$, IL-6, and IL-8) may activate neutrophils and promote them to migrate through the endothelium, subepithelial matrix, and basement membrane of blood and lymph vessels into the infected mammary gland. Neutrophils then pass through the tight junction between the alveolar epithelial cells and enter into the alveolus to secrete cellular Hp (please see review article for more detail [27]) (pathway 1). Second, plasma Hp of hepatic origin mimicking albumin and immunoglobulin [11,20] is able to directly enter into the epithelial cells via a receptor-mediated process and secrete into alveolus (including endocytosis and exocytosis) (pathway 2). Third, plasma $\mathrm{Hp}$ is able to spill into the udder by passive diffusion through a compromised udder/vascular system barrier (pathway 3). Fourth, the mammary epithelial cells are able to endogenously synthesize and express $\mathrm{Hp}$ in the alveolus (pathway 4). (A color version of this figure is available at www.vetres.org.)

Acknowledgements. This work was supported by Grants NSC (94-95)-2313-B-009-001, 95-2313-B009-003-MY2 and 97-2313-B-009-001-MY2 (SJTM) and NSC 94-2313-B-020-023 (JWL) from the National Science Council, Taiwan, R.O.C. We also thank James Lee of the National Chiao Tung University for critical review of this manuscript.

\section{REFERENCES}

[1] Boulanger V., Zhao X., Lacasse P., Protective effect of melatonin and catalase in bovine neutrophilinduced model of mammary cell damage, J. Dairy Sci. (2002) 85:562-569.

[2] Chen W.L., Hwang M.T., Liau C.Y., Ho J.C., Hong K.C., Mao S.J.T., $\beta$-Lactoglobulin is a thermal marker in processed milk as studied by electrophoresis and circular dichroic spectra, J. Dairy Sci. (2005) 88:1618-1630.

[3] Chen W.L., Liu W.T., Yang M.C., Hwang M.T., Tsao J.H., Mao S.J.T., A novel conformationdependent monoclonal antibody specific to the native structure of $\beta$-lactoglobulin and its application, J. Dairy Sci. (2006) 89:912-921.

[4] Cooray R., Waller K.P., Venge P., Haptoglobin comprises about $10 \%$ of granule protein extracted from bovine granulocytes isolated from healthy cattle, Vet. Immunol. Immunopathol. (2007) 119:310-315.

[5] Eckersall P.D., Young F.J., McComb C., Hogarth C.J., Safi S., Weber A., et al., Acute phase proteins in serum and milk from dairy cows with clinical mastitis, Vet. Rec. (2001) 148:35-41. 
[6] Eckersall P.D., Young F.J., Nolan A.M., Knight C.H., McComb C., Waterston M.M., et al., Acute phase proteins in bovine milk in an experimental model of Staphylococcus aureus subclinical mastitis, J. Dairy Sci. (2006) 89:1488-1501.

[7] Gervois P., Kleemann R., Pilon A., Percevault F., Koenig W., Staels B., Kooistra T., Global suppression of IL-6-induced acute phase response gene expression after chronic in vivo treatment with the peroxisome proliferator-activated receptor- $\alpha$ activator fenofibrate, J. Biol. Chem. (2004) 279:16154-16160.

[8] Grönlund U., Hallén Sandgren C., Persson Waller K., Haptoglobin and serum amyloid A in milk from dairy cows with chronic sub-clinical mastitis, Vet. Res. (2005) 36:191-198.

[9] Hiss S., Mielenz M., Bruckmaier R.M., Sauerwein H., Haptoglobin concentrations in blood and milk after endotoxin challenge and quantification of mammary Hp mRNA expression, J. Dairy Sci. (2004) 87:37783784.

[10] Huynh H.T., Robitaille G., Turner J.D., Establishment of bovine mammary epithelial cells (MAC-T): an in vitro model for bovine lactation, Exp. Cell Res. (1991) 197:191-199.

[11] Kolb A.F., Engineering immunity in the mammary gland, J. Mammary Gland Biol. Neoplasia (2002) 7:123-134.

[12] Kristiansen M., Graversen J.H., Jacobsen C., Sonne O., Hoffman H., Law S.K., Moestrup S.K., Identification of the haemoglobin scavenger receptor, Nature (2001) 409:198-201.

[13] Lai I.H., Tsai T.I., Lin H.H., Lai W.Y., Mao S.J.T., Cloning and expression of human haptoglobin subunits in Escherichia coli: delineation of a major antioxidant domain, Protein Expr. Purif. (2007) $52: 356-362$.

[14] Lai I.H., Lin K.Y., Larsson M., Yang M.C., Shiau C.H., Liao M.H., Mao S.J.T., A unique tetrameric structure of deer plasma haptoglobin: an evolutionary advantage in the Hp 2-2 phenotype with homogeneous structure, FEBS J. (2008) 275: 981-993.

[15] Lai Y.A., Lai I.H., Tseng C.F., Lee J., Mao S.J.T., Evidence of tandem repeat and extra thiol-groups in the polymeric formation of bovine haptoglobin: a unique structure of Hp 2-2 phenotype, J. Biochem. Mol. Biol. (2007) 40:1028-1038.

[16] Langlois M.R., Delanghe J.R., Biological and clinical significance of haptoglobin polymorphism in humans, Clin. Chem. (1996) 42:1589-1600.

[17] Lauzon K., Zhao X., Bouetard A., Delbecchi L., Paquette B., Lacasse P., Antioxidants to prevent bovine neutrophil-induced mammary epithelial cell damage, J. Dairy Sci. (2005) 88:4295-4303.

[18] Lee J.W., Zhao X., Recombinant human interleukin-8, but not human interleukin-1beta, induces bovine neutrophil migration in an in vitro co-culture system, Cell Biol. Int. (2000) 24:889-895.

[19] Merle R., Schröder A., Hamann J., Cell function in the bovine mammary gland: a preliminary study on interdependence of healthy and infected udder quarters, J. Dairy Res. (2007) 74:174-179.

[20] Monks J., Neville M.C., Albumin transcytosis across the epithelium of the lactating mouse mammary gland, J. Physiol. (2004) 560:267-280.

[21] Nielsen B.H., Jacobsen S., Andersen P.H., Niewold T.A., Heegaard P.M., Acute phase protein concentrations in serum and milk from healthy cows, cows with clinical mastitis and cows with extramammary inflammatory conditions, Vet. Rec. (2004) $154: 361-365$

[22] Olde Riekerink R.G., Barkema H.W., Veenstra W., Berg F.E., Stryhn H., Zadoks R.N., Somatic cell count during and between milkings, J. Dairy Sci. (2007) 90:3733-3741.

[23] Pedersen L.H., Aalbaek B., Røntved C.M., Ingvartsen K.L., Sorensen N.S., Heegaard P.M., Jensen H.E., Early pathogenesis and inflammatory response in experimental bovine mastitis due to Streptococcus uberis, J. Comp. Pathol. (2003) 128:156-164.

[24] Petersen H.H., Nielsen J.P., Heegaard P.M., Application of acute phase protein measurements in veterinary clinical chemistry, Vet. Res. (2004) 35:163-187.

[25] Poutrel B., Stegemann M.R., Roy O., Pothier F., Tilt N., Payne-Johnson M., Evaluation of the efficacy of systemic danofloxacin in the treatment of induced acute Escherichia coli bovine mastitis, J. Dairy Res. (2008) 75:310-318.

[26] Pyörälä S., Indicator of inflammation in the diagnosis of mastitis, Vet. Res. (2003) 34:565-578.

[27] Rainard P., Riollet C., Innate immunity of the bovine mammary gland, Vet. Res. (2006) 37:369-400.

[28] Theilgaard-Mönch K., Jacobsen L.C., Nielsen M.J., Rasmussen T., Udby L., Gharib M., et al., Haptoglobin is synthesized during granulocyte differentiation, stored in specific granules, and released by neutrophils in response to activation, Blood (2006) 108:353-361.

[29] Thielen M.A., Mielenz M., Hiss S., Zerbe H., Petzl W., Schuberth H.J., et al., Short communication: Cellular localization of haptoglobin mRNA in the experimentally infected bovine mammary gland, J. Dairy Sci. (2007) 90:1215-1219. 
[30] Tseng C.F., Lin C.C., Huang H.Y., Liu H.C., Mao S.J.T., Antioxidant role of human haptoglobin, Proteomics (2004) 4:2221-2228.

[31] Tseng C.F., Mao S.J.T., Analysis of antioxidant as a therapeutic agent for atherosclerosis, Curr. Pharm. Anal. (2006) 2:369-384.
[32] Wagner L., Gessl A., Parzer S.B., Base W., Waldhäusl W., Pasternack M.S., Haptoglobin phenotyping by newly developed monoclonal antibodies. Demonstration of haptoglobin uptake into peripheral blood neutrophils and monocytes, J. Immunol. (1996) 156:1989-1996. 